\title{
Operational vs. Embodied Energy: a Case for Wood Construction
}

\section{Analiza operativne i ugrađene energije drvenih građevina}

\author{
Review paper $\bullet$ Pregledni rad \\ Received-prispjelo: 21. 7. 2014. \\ Accepted-prihvaćeno: 11. 5. 2017. \\ UDK: $630 * 79 ; 630 * 833.0$ \\ doi:10.5552/drind.2017.1423
}

\begin{abstract}
The purpose of our article is to evaluate wood as a construction material in terms of the energy required for its construction and operation, compared to other types of construction materials. First, the role of construction and material manufacturing is evaluated within the full life cycle energy and $\mathrm{CO}_{2}$ emissions of a building, concluding that the issue of embodied energy justifies the use of less energy intensive materials. Then the article reviews the literature dealing with the energy requirements of wood based construction, in order to establish whether the use of this natural, low density construction material is more energy efficient than using brick, reinforced concrete and steel structures. According to our analysis, the vast majority of the studies found that the embodied energy is significantly lower in wood based construction when compared to inorganic materials. According to several authors, wood construction could save much energy and significantly reduce the emissions related to the building sector on the national level. Carbon sequestration, and the related mitigation of the global climate change effect, can be significant if the share of durable wooden buildings can be increased in the market, using sustainably produced raw materials that are handled responsibly at the end of their lifetime. Some conflicting studies make important points concerning the heat storage, recycling and on-site labour demands related to these structures. These sources contribute to a deeper understanding of the issue, but do not alter the basic conclusions concerning the benefits of wood based construction. Some important aspects of wood extraction, manufacturing and construction that can help minimising the embodied energy of wood based structures are also discussed in the study.
\end{abstract}

Key words: climate change, embodied energy, emissions, carbon-dioxide, carbon sequestration, wood based construction

SAŽETAK • Cilj rada bio je ocijeniti drvo kao građevni materijal sa stajališta energije potrebne za proizvodnju građevnog materijala i operativne energije tijekom korištenja građevina, u usporedbi s ostalim vrstama građevnih materijala. Najprije je procijenjena uloga proizvodnje drvnoga građevnog materijala i izgradnje građevine u ukupnoj energiji i emisiji $\mathrm{CO}_{2}$ u životnom ciklusu građevine, te je zaključeno da je, s obzirom na ugrađenu energiju, opravdana upotreba energetski manje intenzivnih materijala. Zatim je dan pregled literature koja se bavi energetskim zahtjevima gradnje na bazi drva, kako bi se utvrdilo je li upotreba toga prirodnoga gradevnog materijala male gustoće energetski učinkovitija od upotrebe opeke, armiranog betona i čeličnih konstrukcija. Prema provedenoj analizi, velik broj studija pokazao je da je ugrađena energija znatno niža u konstrukciji utemeljenoj na drvu nego u onoj od anorganskih materijala. Nekoliko je autora ustvrdilo da se gradnjom na bazi drva može uštedjeti mnogo energije i znatno smanjiti emisije ugljikova dioksida u građevinskom sektoru na nacionalnoj razini. Vezanje uglji-

\footnotetext{
${ }^{1}$ Author is associate professor at University of West Hungary, Simonyi Karoly Faculty of Engineering, Wood Sciences and Applied Arts, Sopron, Hungary.

${ }^{1}$ Autor je izvanredni profesor Sveučilišta zapadne Mađarske, Fakultet inženjerstva, znanosti o drvu i primijenjene umjetnosti, Sopron, Mađarska.
} 
ka i s tim povezano ublažavanje globalnog učinka klimatskih promjena mogu biti veliki ako se poveća udio trajnih drvenih građevina na tržištu, izgrađenih primjenom sirovina proizvedenih održivim gospodarenjem šumama $i$ ako se s građevinama na kraju njihova životnog vijeka odgovorno postupa. Neke studije čiji autori ne podržavaju gradnju drvom smatraju važnim naglasiti pitanja vezana za skladištenje topline i recikliranje te zahtjeve za radnom snagom na terenu pri gradnji objekata na bazi drva. Te studije pridonose boljem razumijevanju problema, ali ne mijenjaju osnovne zaključke o koristima gradnje na bazi drva. U istraživanju se također raspravlja o nekim važnim aspektima dobivanja drva te proizvodnje i ugradnje građevnog drva, koji mogu pridonijeti smanjenju energije ugrađene u drvene građevine.

Ključne riječi: klimatske promjene, ugrađena energija, emisije, ugljikov dioksid, vezanje ugljika, gradnja na bazi drva

\section{INTRODUCTION 1. UVOD}

In the EU and other parts of the world, the mitigation and prevention of anthropogenic environmental impact, and especially greenhouse gas emission, is becoming an increasingly critical question. Building-related emission was identified as one of the most important sources of pollution. Worldwide, much research has been devoted and measures were introduced to mitigate these problems through reducing the amount of non-renewable energy and $\mathrm{CO}_{2}$ emission in residential and commercial structures. The EU resolution that all new buildings built after 2020 should be near-zero operation energy structures (EP\&C 2010) is part of this effort.

The environmental performance and sustainability of buildings is a complex issue. In Europe the CEN/ TC350 is responsible for the development of standardized methods for the assessment of the sustainability aspects of new and existing construction works. The committee developed several standards for the complex assessment of sustainability, including, but not limited to EN 15978:2011 and EN 15804, on the building and product levels, respectively. Furthermore, ISO 14025:2006 deals with the questions of environmental declarations. However, this article focuses primarily on the energy consumption related to residential construction in general, and wood-based construction in particular.

The regulations introduced in and outside of the EU put much emphasis on decreasing the energy used for the operation of the building (the so-called operation energy, related to heating and cooling, as well as to lighting and other processes). In the meantime, the energy used for producing and transporting the construction materials and for the construction process itself (the so-called embodied energy), as well as the related emission, receives much less attention.

The objectives of this article are to examine the importance of embodied energy within the total lifetime energy of residential buildings, and to evaluate wood as a construction material in terms of its lifetime energy balance, compared to traditional inorganic materials. The energy use and emissions of wood based construction is considered and compared to other building materials, and the carbon sequestration potential of wooden buildings is discussed. The counter-arguments of wood based construction are also analysed.
Finally, we provide recommendations for maximising the environmental advantages of wood through minimising its embodied energy.

\section{EMBODIED VS. OPERATIONAL ENERGY 2. UGRAĐENA ENERGIJA NASUPROT OPERATIVNOJ}

The determination of embodied energy (i.e. the energy used for producing the building materials, their transportation and construction of a building, as well as the maintenance and demolition or deconstruction-related energy) is a very complicated process. There are several methods that may be employed. Process analysis (including the Life-Cycle Assessment methodology widely used and accepted in Europe) works well in known processes, but in many cases, in-depth information is missing about certain processes, and system boundaries are hard to determine. Using different databases may lead to a large variation in the results. Input-output analysis examines the energy requirements and emissions of an entire industry. This very practical, simple method does not differentiate between products and technologies within the given industry, which may differ significantly. Hybrid analysis may improve the precision of the assessment (Hammond and Jones, 2008; Stephan et al., 2011; Crawford and Stephan, 2013). Depending on the applied method, the calculated embodied energy may vary significantly (Crawford and Stephan, 2013).

Most studies focus on the resources invested before completing the construction (the so-called cradleto-gate approach). However, total embodied energy should include maintenance and deconstruction processes, as well. There are several further sources of uncertainty in the determination of embodied energy, as pointed out by Dixit et al. (2010).

Based on the above, the objective determination of the average embodied energy related to a given construction material or a type of building is a very difficult task. This is one reason why, so far, more attention has been paid to operation energy than to embodied energy - especially in terms of government policies. However, difficulties and uncertainties in determining the embodied energy is not a good enough reason to disregard this potentially important environmental factor when considering the environmental impact of a building. 


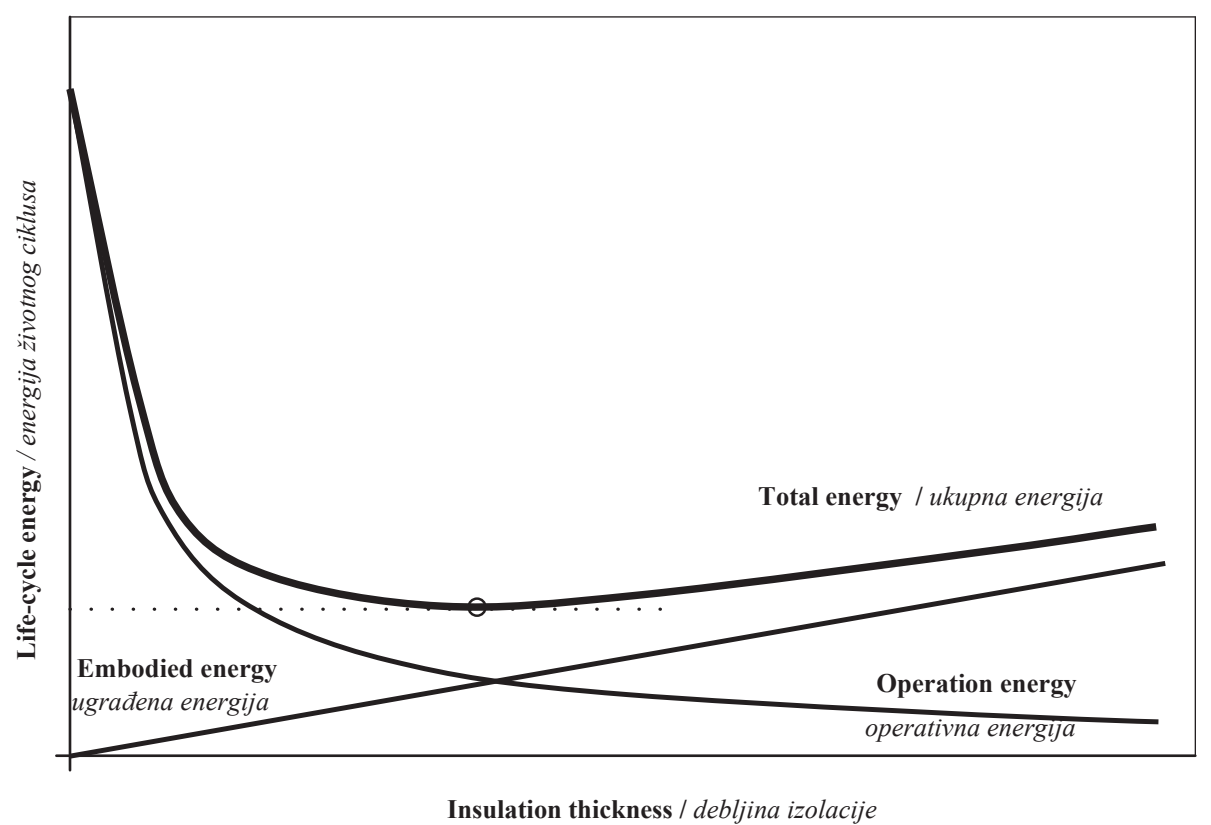

Figure 1 The relationship between embodied, operation and total life-cycle energy as a function of improved thermal insulation of buildings (based on Wind and Heschl 2008)

Slika 1. Odnos između ugrađene energije, operativne energije i energije ukupnoga životnog ciklusa u funkciji poboljšanja toplinske izolacije zgrada (prema Wind i Heschl, 2008.)

Determining operation energy, while not without its challenges, is much more straightforward than determining embodied energy. Operation energy measurement is done simply by measuring the amount of energy sources entering the building. Life cycle energy requirement is also simple to estimate with relatively good precision. Nevertheless, as some authors point out, there are certain uncertainties in determining operation energy as well, including:

- Fuel or electricity production sometimes also requires energy. The actual energy expenditure should include this extra energy as well, as reflected in the concept of primary energy;

- In addition to the quantity of energy, its 'quality' is also significant. Various types or forms of energy are not directly convertible into one another. Some authors suggest that the concept of 'exergy', which takes this into account, should be used instead (Hernandez and Kenny, 2011);

- Residents' lifestyle is also important. The way the residents use their dwelling, as well as some external factors (e.g. the amount of commuting required) also contribute to the energy use related to the given building (Dutil et al., 2011; Crawford and Stephan, 2013).

This shows that estimating or measuring the operation energy of buildings is not totally straightforward either. Nevertheless, the uncertainties are much smaller than in the case of embodied energy and $\mathrm{CO}_{2}$ emissions.

When comparing life cycle embodied to operation energy, most studies place their relative proportion between 10:90 \% and 20:80 \%, (e.g. Cole and Kernan, 1996; Newton et al., 2000; Scheuer et al., 2003; Sartori and Hestnes, 2007; Hernandez and Kenny, 2011; Ortiz et al., 2009; Ramesh et al., 2010; Szalay, 2012). These studies were conducted at different locations, using different building types and different assumptions, but, by and large, came to similar conclusions.

Others point out that these ratios are not necessarily valid today, and attribute an increasing significance to embodied energy (Dixit et al., 2011). Some researchers argue that the role of operation energy is overestimated within the ecological impact of a building. Some studies even found the significance of embodied energy to be comparable to operation energy in many cases (e.g. Thormak, 2002; Gustavsson and Joelsson, 2010).

The role of embodied energy is especially amplified in low-energy, and in the so-called "zero-energy" buildings, that require thick walls and much (usually very energy-intensive) insulation material. This can mean that, after a point, improving the thermal properties (which leads to decreased operation energy, along with increased embodied energy) does not lead to more improvement in terms of total life-cycle energy and emission, and could in fact start increasing it (Figure 1).

Several studies showed that passive houses have much higher embodied energy content than traditional buildings (Dahlstrom, 2011; Thiers and Peuportier, 2012; Crawford and Stephan, 2013). Depending on the applied calculation method, their total life cycle energy and $\mathrm{CO}_{2}$ emission may be even higher than in standard houses (Crawford and Stephan, 2013.) Other authors maintain that passive houses are definitely more energy efficient on the whole, but their total environmental impact may not be as favourable (Brunklaus et al., 2010). Even using more conservative calculation methods, the significance of embodied energy may be high compared to the operation energy when the thermal insulation is improved. Further improvement in the energy efficiency is possible using environment friendly construction materials and technologies only (e.g. Dutil et al., 2011; Szalay, 2012). 
3 ENERGY BALANCE OF WOOD EXTRACTION AND BUILDING MATERIAL PRODUCTION COMPARED TO OTHER MATERIALS

3. ENERGETSKA BILANCA PRIDOBIVANJA DRVA I PROIZVODNJE GRAĐEVNOG MATERIJALA U USPOREDBI S DRUGIM MATERIJALIMA

Many studies available in the literature discuss the environmental impact of wood based construction. Unfortunately, these studies often use different methods and databases, and vary in terms of time, geography and technological capabilities of the analysed construction process. Accordingly, the calculated embodied energy and emission values can greatly diverge (e.g., according to a 2008 study by Hammond and Jones, literature values for the embodied energy of sawnwood range between 0.3 and $61.3 \mathrm{MJ} / \mathrm{kg}$, and other materials show similar variations). Nevertheless, there is a very straightforward tendency when wood and wood based construction is compared to other materials.

In terms of the environmental impact of wood, most authors agree that wood is generally more environmentally friendly than other building materials. Almost all of the studies conclude that wood building elements and buildings require less embodied energy and cause lower $\mathrm{CO}_{2}$ emissions than equivalent brick, concrete or steel structures (Richter and Sell, 1993; Peirquet et al., 1998; Buchanan and Levine, 1999; Dias and Pooliyadda, 2004; Börjesson and Gustavsson, 2000; Lenzen and Treloar, 2002; Sharai-Rad and Welling, 2002; ASMI 2004; Lippke et al., 2004; Perez-Garcia et al., 2005, Puettmann and Wilson, 2005; Gustavsson and Sathre, 2006; Gustavsson et al., 2006; Dutil et al., 2011). One study (Sarri, 2001) found metal to have somewhat lower embodied energy, but in terms of nonrenewable energy and $\mathrm{CO}_{2}$ emissions, wood was still found to have a lower environmental impact.

The production of sawnwood is definitely less energy intensive than that of other materials. Due to its lower density, the extraction as well as the transportation, handling and processing of the raw material requires less energy. In addition, sawmilling by-products (like bark, sawdust, wood chips and trimming) can be used for heat or even electric energy production to partly cover the energy requirements of the mill. Also, used wood can be used at the end of its life cycle to produce more energy, which further improves the energy balance of wooden buildings.

Depending on the particular construction system, wood can be used as glued structural members, rather than solid wood. Because of the embodied energy of the adhesive, as well as the energy requirement of hot pressing, the embodied energy of glued structural members may be 1.5 to 2 times as high, and that of wood based composites may be 3 times of that of sawnwood, according to a North American study (Puettmann and Wilson, 2005). The database of Bath University in Great Britain shows similar differences (Hammond and Jones, 2008): glulam and MDF contain 1.5 times as much embodied energy, plywood and hardboard twice as much, and veneered chipboard 3 times as much as sawn timber. Other modification methods, including preservative and heat treatment, or the fire retardant included in cellulose fibre insulation, can significantly affect the embodied energy (Dutil et al., 2011). According to Puettmann and Wilson (2005), however, the production of wood and wood based products still requires less energy than their inorganic counterparts. Naturally, these processes have other environmental implications, but these are beyond the scope of this review.

As evidenced above, there is a basic consensus regarding the relatively low embodied energy of wood products. In their case study of several buildings, Börjesson and Gustavsson (2000) concluded that the same building contains $60-80 \%$ more embodied energy when built with a concrete structure, as compared to a wood based structure. $\mathrm{CO}_{2}$ emission is at least 1.5 times higher, but may even be several times higher. Lenzen and Treloar (2002) later corrected this study, but they agreed with the conclusions concerning the relative impact of concrete and wood. Szalay (2003) calculated that the embodied energy of concrete and steel buildings is, respectively, $68 \%$ and $136 \%$ higher per square metre, than that of wooden buildings. North American case studies by Lippke et al. (2004), as well as Swedish and Finnish ones by Gustavsson et al. (2005) showed much lower differences of 16-32 \%, but wood was still found more advantageous.

Petersen and Solberg (2005) point out that the results of various studies differ significantly depending on system boundaries, reuse or recycling at the end of the building service life, and other factors, but state that substituting wood for concrete or steel significantly decreased the production-related $\mathrm{CO}_{2}$ emissions in all cases. Based on the ISO 14040 standard and the PAS 2050 ecological footprint determination methodology, Murphy (2009) regards wood as a green building material that has a positive effect on the climate change. He also points out that some information concerning the effect of wood needs to be refined. Gustavsson and Joelsson (2010) emphasise the importance of embodied energy and argue that the application of wood can significantly reduce the detrimental environmental effect of buildings.

Several studies examined the effect of the proliferation of wood construction on a larger region. Buchanan and Lavine (1999) estimated that, in New-Zealand, the $\mathrm{CO}_{2}$ emission of the construction industry, and the total national emission could be decreased by $20 \%$ and $1.5 \%$, respectively, by increasing the share of wood and wood based materials in the building industry by $17 \%$. Upton et al. (2008) calculated that the total life cycle energy of wooden residential buildings is $20-50 \%$ lower, and, if all residential buildings were wood frame structures in the US, the embodied energy and the related $\mathrm{CO}_{2}$ emissions could be decreased by $22 \%$ and $27 \%$, respectively (and this in a country where most residential buildings are already built with a wooden structure). 


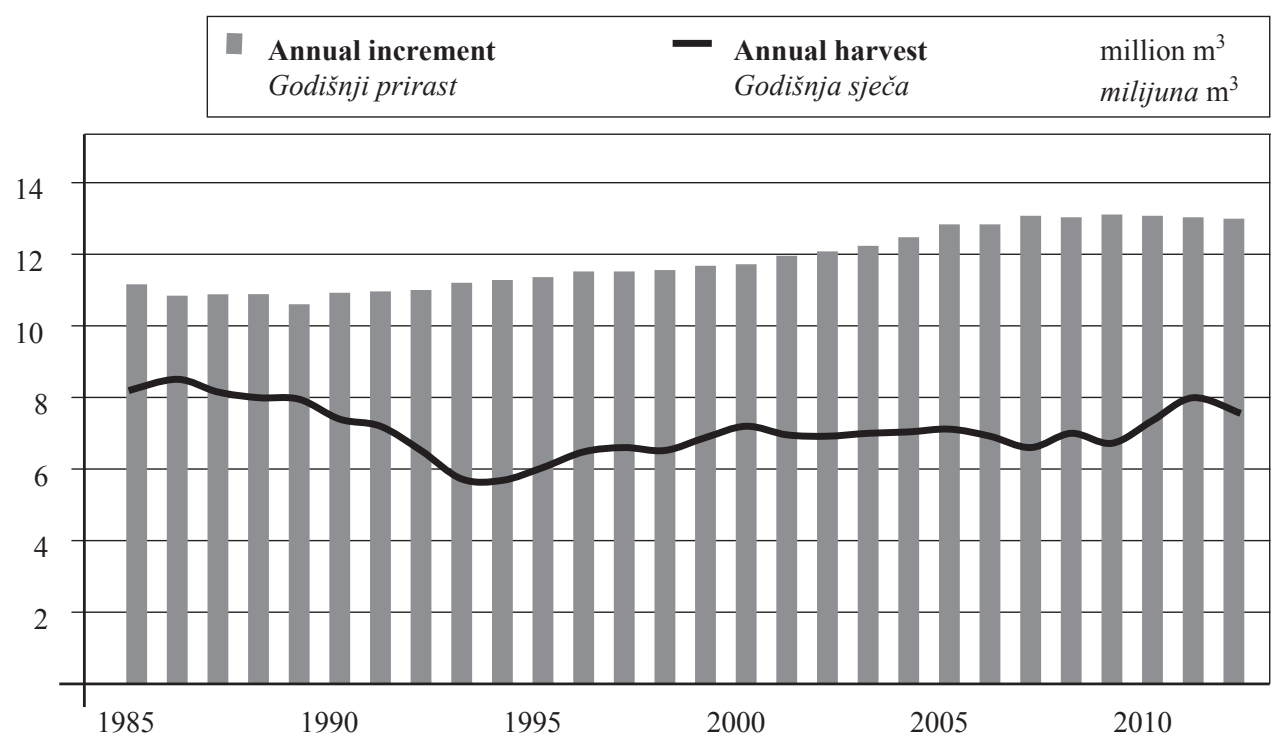

Figure 2 Annual increment and harvest in Hungarian forests (based on NEBIH 2013)

Slika 2. Godišnji prirast i sječa u mađarskim šumama (prema NEBIH, 2013.)

\section{THE ROLE OF CARBON SEQUESTRATION} IN WOODEN BUILDINGS

\section{ULOGA VEZANJA UGLJIKA U DRVENIM} GRAĐEVINAMA

Some of the studies consider the role of wood in carbon sequestration (Buchanon and Levine 1999, Börjesson and Gustavsson 2000, Lippke et al. 2004, Szalay 2004). However, this factor is often disregarded as one that is hard to compare with other indicators (Hammond and Jones 2008), or because the carbon stored in wood will eventually return to the atmosphere. Thus, the architectural use of wood is only advantageous compared to other wood products $(\mathrm{Bu}-$ chanan and Levine, 1999). Other studies state that the energy balance of "wood-intensive" buildings may be positive if wood comes from sustainable sources and is used for energy production at the end of its life cycle (Szalay, 2004; Salazar and Meil, 2009). According to Murphy (2009), carbon sequestration results in negative global warming potential, although he points out that this is very much a function of its reuse or recycling at the end of its life cycle (which is seldom actually studied; most models rely on assumptions).

Based on Hungarian studies by Schoberl et al. (2011) and Schoberl (2012), and also the above considerations, the following conclusions can be drawn, concerning carbon sequestration:

- The carbon sequestration effect of wood is useful only if the harvested material is continuously replenished, i.e., if it comes from sustainable forests. Fortunately, this is true in most of Europe. In Hungary, for example, the yearly increment shows a generally increasing

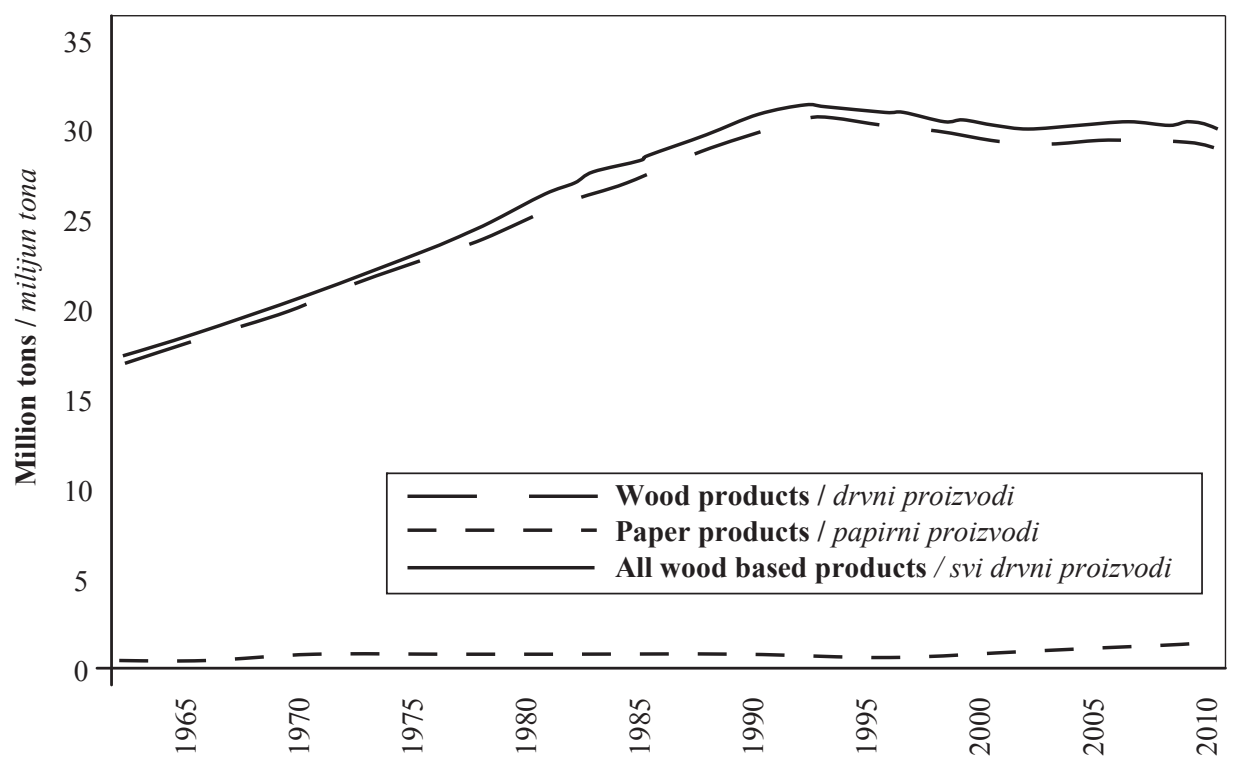

Figure 3 The amount of carbon stored in wood and paper products in Hungary (based on Schoberl, 2011)

Slika 3. Količina ugljika pohranjena u drvnim proizvodima i proizvodima od papira u Mađarskoj (Schoberl, 2011.) 
trend, while the harvest amounts to only about $50 \%$ of the increment (Schiberna, 2011, Figure 1.).

- On the regional or national level, positive carbon sequestration requires the amount of wooden tools or products, and therefore the volume of carbon stored in them, to increase. According to the statistics, although it used to show a steady increase in Hungary until the mid-1990s, right now it is stagnating, or only slightly increasing (Figure 2). According to Schoberl et al. (2011), one way of increasing the stock of carbon stored in wood in Hungary would be to increase the share of wood within the construction industry.

- The service life of buildings, and the handling of building materials at the end of their life cycle is a key issue (Börjesson and Gustavsson, 2000). Wood fibres in construction wood constitute an important resource. The deconstructed material may be reused as construction wood or recycled into other materials (e.g. wood based panels, composites or paper). Thus, the carbon may not be released into the atmosphere as carbon-dioxide for a long time. Energy use also has a positive effect, but it results in a rapid release of the carbon into the atmosphere. Therefore, it should be encouraged, but only when wood is no longer serviceable in any other capacity. Depositing wood in landfills is the worst possible solution, since there the carbon will turn into $\mathrm{CO}_{2}$ relatively quickly (depending on the durability of the wood species), and there is no energy gain. One should strive to reuse or recycle the deconstructed material at the highest possible level, and preferably several times.

An increased proportion of wooden buildings, built of material coming from sustainable forests, and handled responsibly at the end of their lifetime, can significantly contribute to the long term sequestration of atmospheric carbon, and, consequently, to the mitigation of global climate change.

\section{POTENTIAL PITFALLS OF WOOD BASED CONSTRUCTION \\ 5. MOGUĆI NEDOSTACI DRVA KAO GRAĐEVNOG MATERIJALA}

Some authors bring forth arguments that may counteract the perceived benefits of wood construction, compared to inorganic materials.

The surface mass and the related daily and seasonal heat storage capacity of buildings are generally disregarded when comparing wood to traditional building materials. Hacker et al. (2008) calculate that, although the amount of $\mathrm{CO}_{2}$ released during wood construction is much lower, considering the seasonal heat equalization coming from the higher thermal mass of concrete buildings, and the resulting savings in heating and cooling, the difference may be balanced in terms of life-cycle energy. Several other studies, financed by the American Portland Cement Association, also emphasise the energy saved due to the thermal mass of concrete buildings (Gajda, 2001; Marceau and Van Geem, 2002a, b, c). In Upton's (2008) evaluation, however, the embodied energy calculations are not detailed in these studies, and the thermal insulation of systems compared is not equivalent.

These studies are important in terms of pointing out the significance of thermal mass (which is especially important in areas with high seasonal temperature fluctuation, like most of Europe). Nevertheless, due to the above mentioned deficiencies, it is questionable whether the higher thermal mass provides enough of a benefit to make concrete a more energy efficient building material than wood. In addition, some wood construction systems may also possess a relatively high thermal mass. Several studies (Crespell and Gagnon 2010, TRADA 2010) mention the high thermal mass of CLT (Cross-Laminated Timber), for example. The examination of the Holz100 system by the Erwin Thoma $\mathrm{GmbH}$, for example, revealed that the cool-off time of a building manufactured from their product may be three times as long as that of an equivalent brick building, based on a TRYNSYS simulation model (Kouba, 2001). Szalay (2004b) published a theoretical study, where she calculated that the daily heat equalization may be significantly better in solid wood buildings than in the case of insulated brick buildings, and even claimed that lightframe walls are not much worse than AAC (cellular concrete) walls in this respect.

Other publications (Anderson, 1998; SCI, 1998; de Spot, 1999; Adalbert et al., 2001; SCSSC, 2002) emphasise the advantage of steel. These are mostly based on the recyclability of steel, downplaying the significance of embodied energy, lower needs for steel maintenance and land use issues concerning wood. Upton (2008) counters that, in studies comparing equivalent thermal insulation systems, the embodied energy of wood structures is almost always lower than that of steel framing. In addition, the proponents of steel usually disregard the fact that other materials (like wood) may also be reused or recycled to a certain extent.

Dutil et al. (2011) estimate that wood based construction often requires more on-site labour than steel. The related transportation of workers may diminish the positive ecological effect of wood. Thus the energy balance of steel construction may even be better than wood (although they do acknowledge that wood-related $\mathrm{CO}_{2}$ emissions are still lower). Evaluating the energy balance of on-site construction, Cole (1998) shows that, for concrete buildings, embodied energy and $\mathrm{CO}_{2}$ emissions related to worker transportation is much higher than that of either wood or steel. In his comparison, steel is somewhat better than wood, but it would be a gross exaggeration to say that this may cause steel structures to have lower embodied energy than wood. In addition, these comparisons are highly dependent on the particular technology employed (especially on the level of prefabrication, which may be very high in wood buildings).

In summary, these considerations aid a better understanding of the benefits of wood, but do not change the basic conclusion that wood based construction leads to much lower embodied energy and $\mathrm{CO}_{2}$ emissions than in the case of inorganic building materials. 


\section{TAKING BEST ADVANTAGE OF THE} ENERGY BENEFITS OF WOOD

6. ISKORIŠTAVANJE ENERGETSKIH PREDNOSTI DRVA NA NAJBOLJI NAČIN

Based on the review of the available literature, wood based construction uses less energy than other construction technologies. In the meantime, the details of this technology, like the acquisition, handling, transportation of the resources and workers, can be optimised to further improve the energy efficiency. Some of these are listed, as follows:

\section{Certification}

As mentioned earlier, some advantages of wood cannot be realised only if it comes from sustainable forests. European raw materials are typically like this, since most of Europe practices sustainable forestry. In the meantime, full certainty of sustainability is guaranteed only through buying certified materials. Soon, all of Europe will move toward accepting FSC or PEFC (Forestry Stewardship Council, Programme for the Endorsement of Forest Certification, respectively) certified materials only.

\section{Transportation}

Since wood is produced with relatively low $\mathrm{CO}_{2}$ emission, the importance of processes that release $\mathrm{CO}_{2}$ increases. This includes the shipping of material. Since, in Hungary, construction wood is typically bought from abroad, transportation may significantly increase $\mathrm{CO}_{2}$ emissions, depending on the country of origin.

Assuming that an average diesel truck is used, $4.5 \times 10^{-5} \mathrm{~kg}$ of $\mathrm{CO}_{2}$ is released when hauling one $\mathrm{kg}$ of wood over a one kilometre distance ${ }^{1}$. According to the embodied carbon and energy inventory of the British Bath University, the embodied carbon of softwood lumber is $0.123 \mathrm{~kg} / \mathrm{kg}$, i.e. $0.45 \mathrm{~kg}$ of $\mathrm{CO}_{2}$ is released when producing one $\mathrm{kg}$ of wood. Accordingly, the emissions related to transporting the material one kilometre is four orders of magnitude lower than that related to its production. This means that, even if wood travels $1000 \mathrm{~km}$, there is only a slight emission increase. The calculations do not include other emissions arising from transportation (like producing and maintaining the vehicles and roads), and are not based on primary emissions, therefore the actual emissions are somewhat higher.

Nevertheless, wood should be acquired from as near as possible, preferably from domestic sources. Unfortunately, Hungarian climate and sites are not suitable for growing softwood of sufficient quality, but some poplar species may be suitable for substituting softwood. This may allow us to decrease the embodied energy and carbon.

\section{Processing technology}

Even though wood processing typically requires much less energy than other materials, it is still not negligi-

\footnotetext{
According to Davis et al. (2013), transporting $1 \mathrm{~kg}$ material requires approx. $1.7 \times 10^{-5} 1 / \mathrm{kg} / \mathrm{km}$ of diesel fuel. Based on the forumula $\mathrm{C}_{12} \mathrm{H}_{23}+71 \mathrm{O}_{2} \rightarrow 48 \mathrm{CO}_{2}+46 \mathrm{H}_{2} \mathrm{O}, 2.626 \mathrm{~kg} \mathrm{CO}_{2}$ is generated when burning one litre of diesel fuel, taking the density of fuel $(0.832 \mathrm{~kg} / \mathrm{l})$ into account.
}

ble. Wood drying and hot pressing of wood based materials, in particular, are energy intensive processes. To take maximum advantage of the low embodied energy of wood, close attention should be paid to these processes, e.g. through natural drying (which also has a positive effect on wood quality), and using renewable energy sources (especially local energy production using wood processing by-products.)

\section{Adhesives and additives; wood modification}

As the literature shows, using adhesives significantly increases the embodied energy of wood. Impregnating cellulose fibre insulation with fire retardants has a similar disadvantage, and wood preservatives and modification methods (like high temperature treatment and other chemical agents) are also likely to increase the embodied energy. Increasing the dimensions and improving its properties through eliminating defects and re-gluing the material makes it much more suitable for structural applications, and creates higher value (e.g. defect-free, glued structural members allow smaller cross-sections and generate less waste, which has a positive effect on the energy balance and the emissions, too.) Therefore, careful consideration is needed to establish if the use of glued or modified wood is justified. In certain situations their drawbacks may be counterbalanced by the lower volume of required material, or improved durability. Also, developing more environment friendly adhesives and modifying agents is an important area of research.

\section{Prefabrication}

Most on-site processes are very labour-intensive. Related transportation of the workers may be an important factor. Therefore, prefabrication is preferred. Fortunately, most wood-based construction technologies allow high levels of prefabrication, and therefore onsite labour can be minimised.

\section{Resource cascading}

Taking advantage of the energy benefits and the carbon sequestration potential of wood requires reuse and recycling, as many times as possible. The repeated utilisation of the used material, at the highest possible value, is called cascading (Frühwald et al., 2010). This requires a paradigm-shift, over which builders have little or no control. One way to foster cascading is using as much used material in the buildings, as possible. Using wood for energy production should be the last step of cascading. The energy gained at the end of the life cycle may be comparable, or even higher than the energy used for manufacturing the product. This energy may be taken into account in the LCA (Life Cycle Assessment) methodology, too.

\section{CONCLUSIONS}

\section{ZAKLJUČAK}

The aim of our study was to establish if wood based construction is environment friendly based on embodied energy and $\mathrm{CO}_{2}$ emission. Based on an indepth study of the literature, the following conclusions were drawn: 
1. Embodied energy can account for upwards of $20 \%$ of the total lifecycle energy of buildings. Minimising the embodied energy incorporated in the building is especially important in modern, energy efficient buildings where the relative importance of operation energy decreases, and embodied energy increases due to the larger volume of construction material required.

2. Based on most studies, manufacturing and using wood and wood based materials in buildings leads to much lower embodied energy and $\mathrm{CO}_{2}$ emissions, compared to inorganic building materials. Most authors calculate that this leads to reduction in emissions and in the life-cycle energy of the buildings.

3. Increasing the share of wooden structures within the construction industry, built from sustainable and high-quality (durable) raw materials, and handled responsibly at the end of the building service life, may significantly contribute to the sequestration of atmospheric carbon dioxide on the long run. This may be an important strategy in mitigating the problem of global climate change.

4. There are certain considerations that can amend the positive conclusions concerning the benefits of wood in terms of energy use and emissions. However, these studies failed to prove that inorganic building materials may be better than wood in this respect.

5. Optimising certain aspects of the production of building materials and of the construction technology has a potential to further improve the energy efficiency of wood based construction. These strategies are outlined in detail in the article.

Based on the above, the final conclusion is that the use of wood in the construction industry carries significant environmental advantages in terms of energy efficiency and emission reduction.

\section{Acknowledgements - Zahvala}

This article was made in frame of the „EFOP3.6.1-16-2016-00018 - Improving the role of research+development+innovation in the higher education through institutional developments assisting intelligent specialization in Sopron and Szombathely.

\section{REFERENCES}

\section{LITERATURA}

1. Adalberth, K.; Almgren, A.; Holleris Petersen, E., 2001: Life cycle assessment of four multi-family buildings. International Journal of Low Energy and Sustainable Buildings, 2.

2. Anderson, J., 1998: Development of an environmental research strategy in Sweden. Journal of Construction Steel Research, 46(1/3): 13-14.

https://doi.org/10.1016/S0143-974X(98)00053-4

3. Börjesson, P.; Gustavsson, L., 2000: Greenhouse gas balanced in building construction: wood versus concrete from life-cycle and forest land-use perspectives. Energy Policy, 28: 575-588.

https://doi.org/10.1016/S0301-4215(00)00049-5.
4. Brunklaus, B.; Thormark, C.; Baumann, H., 2010: Illustrating limitations of energy studies of buildings with LCA and actor analysis. Building Research \& Information, 38(3): 265-279.

https://doi.org/10.1080/09613211003654871.

5. Buchanan, A. H.; Levine, S. B., 1999: Wood-based building materials and atmospheric carbon emissions. Environmental Science \& Policy, 2(6): 427-437. https://doi.org/10.1016/S1462-9011(99)00038-6.

6. Cole, R. J.; Kernan, P. C., 1996: Life-Cycle Energy Use in Office Buildings. Building and Environment, 31(4): 307317. https://doi.org/10.1016/0360-1323(96)00017-0.

7. Cole, R. J., 1998: Energy and greenhouse gas emissions associated with the construction of alternative structural systems. Building and Environment, 34: 335-348. https://doi.org/10.1016/S0360-1323(98)00020-1.

8. Crawford, R. H.; Stephan, A., 2013: The significance of embodied energy in certified passive houses. In: Proc. ICCBM 2013: Int. Conf. on Construction and Building Materials, Copenhagen, pp. 473-479.

9. Crespell, P.; Gagnon, S., 2010: Cross-Laminated Timber: a Primer. FPI Special Publication, issue 52.

10. Dahlstrom, O., 2011: Life Cycle Assessment of a SingleFamily Residence built to Passive House Standard. Master thesis, Norwegian University of Science and Technology, Trondheim, Norway.

11. Davis, S. C.; Diegel, S. W.; Boundy, R. G.; Moore, S., 2013: Vehicle Technologies Market Report. Report for the US Dept. of Energy. ORNL/TM-2014/58, Oak Ridge National Laboratory, Oak Ridge, TN. https://doi.org/10.2172/1068745.

12. Dias, W. P. S.; Pooliyadda, S. P., 2004: Quality based energy contents and carbon coefficients for building materials: A systems approach. Energy, 29(4): 561-580. https:// doi.org/10.1016/j.energy.2003.10.001.

13. Dixit, M. K.; Fernández-Solís, J. L.; Lavy, S.; Culp, C. H., 2010: Identification of parameters for embodied energy measurement: A literature review. Energy and Buildings, 42: 1238-1247. https://doi.org/10.1016/j.enbuild.2010.02.016.

14. Dutil, Y.; Rousse, D.; Quesada, G., 2011: Sustainable Buildings: An Ever Evolving Target. Sustainability, 3: 443-464. https://doi.org/10.3390/su3020443.

15. Frühwald, A.; Diederichs, S.; Morgan, R., 2010: Verwendungspotentiale heben durch Kaskadennutzung am Beispiel Holz. Erneuerbare Energie, 4: 37-49.

16. Gajda, J., 2001: Energy use of single-family houses with various exterior walls. PCA CD026. Skokie, IL: Portland Cement Association.

17. Gustavsson, L.; Joelsson, A., 2010: Life cycle primary energy analysis of residential buildings. Energy and Buildings, 42: 210-220. https://doi.org/10.1016/j.enbuild.2009.08.017.

18. Gustavsson, L.; Sathre, R.; Pingoud, K., 2006: Greenhouse Gas Benefits of Wood Substitution: Comparing Concrete- and Wood-Framed Buildings in Finland and Sweden. IEA Bioenergy: T38 (2005): 05.

19. Gustavsson, L.; Sathre, R., 2006: Variability in energy and carbon dioxide balances of wood and concrete building materials. Building and Environment, 41: 940-951. https://doi.org/10.1016/j.buildenv.2005.04.008.

20. Gustavsson, L.; Pingoud, K.; Sathre, R., 2006: Carbon dioxide balance of wood substitution: comparing concrete- and wood-framed buildings. Mitigation and Adaptation strategies for global change, 11(3). Netherlands: Springer. https://doi.org/10.1007/s11027-006-7207-1.

21. Hacker, J. N.; De Saulles, T. P.; Minson, A. J.; Holmes, M. J., 2008: Embodied and operational carbon dioxide 
emissions from housing: A case study on the effects of thermal mass and climate change. Energy and Buildings, 40: $375-384$.

https://doi.org/10.1016/j.enbuild.2007.03.005.

22. Hammond, G. P.; Jones, C. I., 2008: Embodied energy and carbon in construction materials. Proceedings of the Inst. of Civil Engineers, 161(2): 87-98.

https://doi.org/10.1680/ener.2008.161.2.87.

23. Hernandez, P.; Kenny, P., 2011: From net energy to zero energy buildings: Defining life cycle zero energy buildings. Energy and Buildings, 42: 815-821. https://doi.org/10.1016/j.enbuild.2009.12.001.

24. Kouba, R., 2001: Thermische Simulation zum Holz100 Bausystem. Research report, Institut für Wärmetechnik, TU Graz, Austria.

25. Lenzen, M.; Treloar, G., 2002: Rejoinder to: Greenhouse gas balanced in building construction: wood versus concrete from lifecycle and forest land-use perspectives. Energy Policy, 30: 249-255. https://doi.org/10.1016/S0301-4215(01)00142-2.

26. Lippke, B.; Wilson, J.; Perez-Garcia, J.; Bowyer, J.; Meil, J., 2004: CORRIM: life-cycle environmental performance of renewable building materials. Forest Prod. J. 54(6): 8-19.

27. Marceau, M.; Van Geem, M., 2002: Life cycle assessment of an insulating concrete form house compared to a wood frame house. SN2571. Skokie, IL: Portland Cement Association.

28. Marceau, M.; Van Geem, M., 2002: Life cycle assessment of a concrete masonry house compared to a wood frame house. SN2465. Skokie, IL: Portland Cement Association.

29. Marceau, M.; Van Geem, M., 2002: Life cycle assessment of a lightweight concrete masonry house compared to a wood frame house. SN2573. Skokie, IL: Portland Cement Association.

30. Murphy, R., 2009: Incorporating Life Cycle Assessment (LCA) of wood materials in green building design. UNECE/FAO Workshop on Responding to Climate Change: Wood's place in a global approach to green building, 12 October 2009, Geneva.

31. Newton, P.; Tucker, S.; Ambrose, M.; 2000: Housing Form, Energy Use and Greenhouse Gas Emissions. In: M. Jenks, K. Williams, E. Burton (ed.). Achieving Sustainable Urban Form. Taylor \& Francis, London, pp. 74-83.

32. Ortiz, O.; Castells, F.; Sonnemann, G., 2009: Sustainability in the construction industry: A review of recent developments based on LCA. Construction and Building Materials, 23: 28-39.

https://doi.org/10.1016/j.conbuildmat.2007.11.012.

33. Peirquet, P.; Bowyer, J.; Huelman, P., 1998: Thermal performance and embodied energy of cold climate wall systems. Forest Prod. J., 48(6): 53-60.

34. Perez-Garcia, J.; Lippke, B.; Briggs, D.; Wilson, J.; Bowyer, J.; Meil, J., 2005: The environmental performance of renewable building materials in the context of residential construction. Wood Fiber Sci. CORRIM Special Issue, 37: 3-17.

35. Petersen, A. K.; Solberg, B., 2005: Environmental and economic impacts of substitution between wood products and alternative materials: a review of micro-level analyses from Norway and Sweden. Forest Policy and Economics, 7: 249-259. https://doi.org/10.1016/S1389-9341(03)00063-7.

36. Puettmann, M.; Wilson, J., 2005: Life-cycle analysis of wood products; cradle-to-gate LCI of residential wood building materials. Wood Fiber Sci. CORRIM Special Issue, 37: 18-29.
37. Ramesh, T.; Prakash, R.; Shukla, K. K., 2010: Life cycle energy analysis of buildings: An overview. Energy and Buildings, 42: 1592-1600. https://doi.org/10.1016/j.enbuild.2010.05.007

38. Richter, K.; Sell, J., 1993: Life-cycle analysis: a useful approach to promote wood as a construction material. Wood Design Focus, 4(2): 14-17.

39. Salazar, J.; Meil, J., 2009: Prospects for carbon-neutral housing: the influence of greater wood use on the carbon footprint of a single-family residence. Journal of Cleaner Production, 17: 1563-1571. https://doi.org/10.1016/j.jclepro.2009.06.006.

40. Sarri, A., 2001: Environmental specifications of building parts and buildings [in Finnish]. TKK Rakentamistalous. Sponsored by Rakennustieto Oy. Helsinki: Rakennustietosaatio RTS. (CORRIM Special Issue).

41. Sartori, I.; Hestnes, A. G., 2007: Energy Use in the Life Cycle of Conventional and Low-Energy Buildings: A Review Article. Energy and Buildings, 39: 249-257. https://doi.org/10.1016/j.enbuild.2010.05.007.

42. Scharai-Rad, M., Welling, J., 2002: Environmental and energy balances of wood products and substitutes. Food and Agriculture Organization of the United Nations (FAO).

43. Scheuer, C.; Keoleian, G. A.; Reppe, P., 2003: Life Cycle Energy and Environmental Performance of a New University Building: Modeling Challenges and Design Implications. Energy and Buildings, 35(10): 1049-1064. https://doi.org/10.1016/S0378-7788(03)00066-5.

44. Schiberna, E., 2011: Fenntartható (tartamos) erdőgazdálkodás (Sustainable forest management) (in Hugarian). In: S. Molnar (ed.). Örök társunk a fa. NymE Publishers, Sopron, Hungary, pp. 11-15.

45. Schoberl, M., 2012: Fatermékekben tárolt szén hazai civilizációs anyagárama és a klíma- védelem. (Material flow of the carbon stored in wood products in Hungary, and the climate protection) (in Hugarian). Faipar, 60(4):10-13.

46. Schoberl, M.; Borcsok, Z.; Fuhrer, E., 2011: Erdő és a faanyag szerepe a klímavédelemben. (The role of forests and wood in climate protection) (in Hugarian). In: S. Molnar (ed.). Örök társunk a fa. NymE Publishers, Sopron, Hungary, pp. 21-26.

47. Stephan, A.; Crawford, R. H.; Myttenaereb, K., 2011: Towards a more holistic approach to reducing the energy demand of dwellings. Procedia Engineering, 21: 10331041. https://doi.org/10.1016/j.proeng.2011.11.2109.

48. De Spot, M., 1999: The application of structural steel to single-family residential construction. Ottawa, Ont.: Node Engineering.

49. Thiers, S.; Peuportier, B., 2012: Energy and environmental assessment of two high energy performance residential buildings. Building and Environment, 51: 276-284. https://doi.org/10.1016/j.buildenv.2011.11.018.

50. Thormak, C., 2002: A low energy building in a life cycle - Its embodied energy, energy need for operation and recycling potential. Building and Environment, 37(4): 429435. https://doi.org/10.1016/S0360-1323(01)00033-6.

51. Szalay, Z., 2003: Embodied Energy in Timber Buildings. In: L. Végh, J. Novák, J. Valentin (eds.). Environmentally Compatible Structures and Structural Materials (ECS). Proc. $4^{\text {th }}$ Int. Seminar on ECS. 19-20 June, 2003. Prague, Czech Republic.

52. Szalay, Z., 2004a: The Role of Timber Buildings in Carbon Storage. In: proc. XXXII IAHS World Congress on Housing Sustainability of the Housing Projects. September 21-25, 2004, Trento, Italy. 
53. Szalay, Z., 2004b: A faszerkezetủ épületek hőtárolóképessége. (The heat storage capacity of timber buildings) (in Hugarian). In: proc. EPKO 2004. International Construction Science Conference. June 3-6, 2004. Sumuleu Ciuc, Romania.

54. Szalay, Z., 2012: Megéri-e közel nulla energiaigényű épületeket építeni? (Is it worth building near-zero energy buildings?) (in Hugarian). Magyar Épületgépészet, 61(11): 3-6.

55. Upton, B.; Miner, R.; Spinney, M.; Heath, L. S., 2008: The greenhouse gas and energy impacts of using wood instead of alternatives in residential construction in the United States. Biomass and Bioenergy, 32: 1-10. https://doi.org/10.1016/j.biombioe.2007.07.001.

56. Wind, G.; Heschl, C., 2008: Graue Energie - ein wesentlicher Faktor zur Energieoptimierung von Gebäuden. Studienzentrum Pinkafeld. http://www.ibwind.at/download/GraueEnergie081121.pdf (Accessed: February 9, 2017).

57. ***Athena Sustainable Materials Institute, 2004: Comparative environmental impact assessment. In: Energy and the environment in residential construction. Sustainable Building Series, no. 1, Canadian Wood Council, pp. 5-11.

58. ***EN 15804:2012 Core product category rules for environmental product assessment. European Committee for Standardisation, Brussels, Belgium, 64 pp.

59. ${ }^{* * *}$ EN 15978:2011 Methodology for environmental assessment of buildings. European Committee for Standardisation, Brussels, Belgium, $64 \mathrm{pp}$.

60. ***ISO 14025:2006 Environmental labels and declarations - Type III environmental declarations - Principles and procedures. International Organization for Standardization, Geneva, Switzerland, $25 \mathrm{pp}$.

61. ***NÉBIH 2013: Erdővagyon, erdőgazdálkodás Magyarországon. (Forest assets and forest management in Hungary.) National Food Chain Safety Office, Forest Management Directoriate, Budapest, Hungary. <https://www. nebih.gov.hu/data/cms/160/852/2013_leporello_magyar_ vx3_jav_masodik_kiad_300dpi.pdf> (in Hugarian).

62. ***Steel Construction Institute, 1998: A comparative environmental life cycle assessment of modern office buildings. Silwood Park, Ascot, Berkshire, UK: The Steel Construction Institute.

63. ***Steel Construction Sector Sustainability Committee, 2002: Sustainable steel construction: building for a better future - a sustainability strategy for the UK steel construction sector. Ascot, Berkshire, UK: The Steel Construction Institute.

64. ***TRADA 2011. Cross-laminated timber: introduction for specifiers. Wood Information Sheet 2.3/61.

\section{Corresponding address:}

Assoc. prof. LASZLO BEJO, Ph. D.

University of Sopron

Simonyi Karoly Faculty of Engineering

Wood Sciences and Applied Arts

Bajcsy-Zs. U. 4

H-9400 Sopron, HUNGARY

e-mail: laszlo.bejo@skk.nyme.hu 